\title{
Can we predict individual investors' behavior in stock markets? A psychological approach*
}

¿Es posible predecir el comportamiento de los inversionistas en los mercados bursátiles? Una aproximación psicológica

Recibido: mayo 11 de 2012 | Revisado: diciembre 17 de 2012 | Aceptado: enero 22 de 2013

\author{
DAVID PASCUAL-EZAMA ** \\ Universidad Complutense de Madrid, España \\ BÁRBARA SCANDROGLIO *** \\ BEATRIZ GIL-GOMEZ DE LIAÑO***** \\ Universidad Autónoma de Madrid, España
}

doi:10.11144/Javeriana.UPSY13-1.cwpi

Para citar este artículo: Pascual-Ezama, D., Scandroglio, B., \& Gil-Gómez, B. (2014). Can we predict individual investors' behavior in stock markets? A psychological approach. Universitas Psychologica, 13(1), 25-35. doi:10.11144/Javeriana.UPSY13-1.cwpi

* Artículo de investigación. Acknowledgments: The authors appreciate the collaboration of Giulio Vidotto and people of Qplab at the University of Padova, Luigi Mittone (University of Trento) and Paul Webley (University of London).

** Universidad Complutense De Madrid. Web: http:// www.davidpascualezama.com/E-mail: dp_ezama@mit.edu

**** Universidad Autónoma de Madrid. Assistant Professor of Social Psychology. E-mail: barbara.scandroglo@uam.es

****** Universidad Autónoma de Madrid, España. Associate Professor of Methodology. E-mail: bgil. gomezdelianno@uam.es

\section{A B S T R A C T}

Understanding financial markets and investors' behavior is one of the biggest objectives in finance. However, most of the research obtained conclusions about individual investors, but they are not studying real individual investors' behavior: they analyzed stock price evolution or used aggregate investor data that essentially belongs to founds and big investors. Psychology has improved financial knowledge and solved many of those financial limitations. Because of that, we decided to apply one of the most valid psychological models to study human behavior, in order to better understand real individual investors' behavior: the Theory of Planned Behavior (TPB; Ajzen, 1991). The model was applied to 127 real investors obtained by the "snowball" technique. According to results, TPB seems to be a good model to understand individual investor's behavior, while explaining $63 \%$ of the investments' intentions and $48 \%$ of the investments' behavior.

Keywords authors

Individual investors' behavior, Theory of Planned Behavior (TPB), Stock Markets, investment decision.

Keywords plus

Consumer behavior, market psychology, quantitative research.

\section{RESUMEN}

Entender los mercados financieros y el comportamiento de los inversionistas es uno de los objetivos principales en materia de finanzas. Sin embargo, se encuentra que la mayor parte de las conclusiones de estas investigaciones sobre los inversionistas no estudian el comportamiento de los mismos: normalmente se encuentra un análisis de la evolución de los precios de las acciones o datos utilizados de inversionistas que pertenecen esencialmente a los grandes mercados. La psicología ha mejorado el conocimiento financiero y ha resuelto muchas de las limitaciones en finanzas. Debido a esto, se ha decidido aplicar uno de los modelos psicológicos más válidos para estudiar el comportamiento humano, con el fin de comprender mejor el comportamiento de los inversionistas. Este modelo es la Teoría del Comportamiento Planeado ([TPB]; Ajzen, 1991). El modelo se aplicó a 127 inversionistas reclutados por la técnica de "bola de nieve”. Según los resultados, el TPB parece ser un buen modelo para comprender el comportamiento de los individuos, al tiempo que explicó el $63 \%$ de la intención de inversión y el 48 \% de la conducta de inversión.

Palabras clave autores

Comportamiento de inversionistas, Teoría del Comportamiento Planeado (TPB), corredores de bolsa, decisiones de inversión.

Palabras clave descriptores

Comportamiento del consumidor, psicología del consumidor, investigación cuantitativa. 


\section{Introduction}

In the classic Economic Theory the rationality of economic agents is one key factor to explain economical processes. However, in recent years, many works have been published about individual investors' behavior showing that different types of investors have different types of biases. That is, researchers have realized about the importance to take into account investors' irrationality in order to understand individual investors' behavior. Recent results have even showed how these irrational behaviors deleteriously affect the financial well being of individual investors (Barber \& Odean, 2011) Because of that, many theoretical models, such as Barberis, Shleifer, and Vishny (1998) or Lovric, Kaymak, and Spronk (2008), have been proposed in order to explain the implications of irrationality in individual investors' behavior in the stock markets.

However, there are very few empirical results of most of these models (although with some exceptions like: Wang, Zhang, \& Hua, 2011). Moreover, the main objective of these models has been focused in the analysis of the main variables or behavioral biases that affect individual investors' decision-making processes. Only in very few papers it has been analyzed in order to predict individual investors' behavior. In our opinion, being able to understand individual investor behavior, and knowing our limitations as humans, is essential to predict individual investors' decision-making processes. Because of that, in the present paper we have applied a psychological theoretical model as an attempt to understand and predict both individual investors' intention and behavior in the stock market.

Human behavior has been studied in the field of Psychology using different models; the Theory of Reasoned Action ([TAR]; Fishbein \& Ajzen, 1975) or the Motivation and Opportunity as Determinants of Processing Model ([MODE]; Fazio, 1986), among others (e.g., Bagozzi \& Kimmel, 1995). However, the Theory of Planned Behavior ([TPB]; Ajzen, 1991) has been probably the most satisfactorily applied model for studying human behavior in a wide variety of situations (Cooke \& Sheeran, 2004). In fact, TPB or a branch of TPB has been applied to study different kind of investment, including ethical (Anand \& Cowton, 1993; Hofmann, Penz, \& Kirchler, 2009; Kurland, 1996; Jansson \& Biel, 2006), informal (Wong \& Ho, 2007), online transactions such as internet stock trading (Grandon, 2005; Ramayah, Rouibah, Gopi, \& Rangel, 2009; Singh, Sandhu, \& Kundu, 2010) or online banking (Rouibah, Ramayah, \& May, 2009; Shih \& Fang, 2004).

Regarding to stock markets individual investment, TPB has been applied to predict investments' intention in a particular sector (East, 1993), to analyze the factors that affect the growth of internet stock trading (Lee-Partridge \& Ho, 2003) or to investigate how stock investors perceive online trading (Lee, 2009). However, in all these works either they don't predict behavior (only intention), nor they use the original building Ajzen's questionnaire, or, more importantly, the sample is not a real investors one (they use students that not necessarily invest in the stock markets). Therefore, we applied TPB trying to solve several limitations found in previous studies.

The paper is organized as follows. The next section reviews model theory as developed in psychology literature and hypotheses derived from the model. Then, we inform about the design and procedure, to finish showing the results and the analyses. The discussion and final conclusions can be found in the last section.

\section{Theory of Planned Behavior}

The TPB is an extension of the Theory of Reasoned Action ([TRA]; Fishbein \& Ajzen, 1975; Ajzen \& Fishbein, 1980) and was proposed to answer a few limitations in the TRA. TRA is limited because it assumes that actions are totally under volitional control: it assumes that individuals are rational, so they have the ability to process and evaluate all of the available information as well as to take into account the effects of their possible actions and base their behavior on this reasoning decision (Fishbein \& Ajzen, 1975; Ajzen \& Fishbein, 1980). The great contribution of the TPB is the introduction of perceived behavioral control. Perceived behavioral 
control includes those non-volitional elements of uncertainty that are beyond individual's volition, thus reflecting the perceived ease or difficulty associated with execution of future behavior. When the adequate degree of actual control and opportunity is present, individuals will be able to act upon this intention and perform the behavior. The perceived behavioral control is specially relevant when individual investment in stock market is analyzed because, on the one hand, it is associated with risks and uncertainty (Thaler, 1980) and, on the other hand, because investors take usually into account a wide range of factors in their decision-taking process (Oberlechner \& Hocking, 2004).

Intention, according to TRA and TPB, is the best predictor of behavior and it is assumed to be the immediate antecedent of behavior (Ajzen, 2002). Hence, attitudes, subjective norms and perceived behavioral control are assumed to have an indirect effect on a given action through their effect on intention. However, in situations where the individuals' volitional control of the action decreases, the intention alone may not be enough to predict action (Ajzen, 1991). In contexts where their personal and/or environmental barriers to behavior exist, perceived behavioral control is assumed to have an independent direct effect on action over and above intention.

According to Ajzen (1991), true to its goal of explaining human behavior, not merely predicting it, the theory of planned behavior, deals with the antecedents of attitudes, subjective norms, and perceived behavioral control, antecedents, which in the final analysis determine intentions and actions. These antecedents are the behavioral, normative and control beliefs that are assumed to influence respectively attitudes towards behavior, subjective norms and perceived behavioral control. According to the expectancy-value model, like the TRA and TPB, people's accessible beliefs about behavior - defined as the subjective probability that behavior will produce a certain outcome - determine their attitudes towards any behavior (Fishbein \& Ajzen, 1975). Specifically, the evaluation of each outcome contributes to the attitude, in direct proportion, to the person's subjective probability that the behavior produces the outcome in question (Hrubes, Ajzen, \& Daigle, 2001). Normative beliefs are concerned with the likelihood that important referents approve or disapprove of performing a given behavior by the person's motivation to comply with the referent in question (Ajzen, 1991). Control beliefs include different factors related to the presence or absence of requisite resources and opportunities by the perceived power of the particular control factor, in order to facilitate or inhibit performance of behavior (Ajzen, 1991).

Regarding the power of TPB factors to predict real behavior, Sheeran (2002) reported that intention accounted for almost one-third of the variance in behavior, while intentions and perceived behavior control predict between $28 \%$ and $34 \%$ of the variance in behavior (Armitage \& Conner, 2001; Godin \& Kok, 1996; Trafimow, Sheeran, Conner, $\&$ Finlay, 2002). Equally, attitudes, subjective norms and perceived behavioral control were accounting for between $39 \%$ and $42 \%$ of the variance for intentions (Armitage \& Conner, 2001; Godin \& Kok, 1996; Sheeran \& Taylor, 1999). Therefore the theory of planned behavior can provide a theoretical framework for current research about factors that influence individual's investment behavior in the stock market. Because of that, we have selected the Theory of Planned Behavior (TPB) in order to explain and predict the behavior of individual investors in the stock exchange, and have hypothesized that it is a good model to explain and predict individual investors' behavior.

In agreement to that and, according to usual TPB predictions (Figure 1), we have also hypothesized that:

H1: An individual investor's intention towards investing in stocks exchange will be positively associated with behavior towards investing in stocks exchange.

H2: An individual investor's attitudes towards investing in stocks exchange will be positively associated with behavioral intentions towards investing in stocks exchange.

H3: An individual investor's subjective norms towards investing in stocks exchange will be positively associated with behavioral intentions towards investing in stocks exchange. 
H4: An individual investor's perceived behavioral control toward investing in stocks exchange will be positively associated with behavioral intentions towards investing in stocks exchange.

H5: Attitudinal beliefs, normative beliefs and perceived control beliefs will be positively related with, respectively, attitude, subjective norm and perceived behavioral control.

\section{Method}

As we previously mentioned, we applied the TPB trying to solve several limitations found in previous studies. Contrary to many other studies, our sample consists of real investors (avoiding student samples) in real markets (no simulations) without any kind of restrictions (full markets, not only a particular sector). In addition, we have used the original TPB questionnaire and we have measured not only intention but also behavior.

\section{Sample}

127 individual investors, from the Spanish stock exchange, participated in this study (48\% women and $52 \%$ men). The average age was $28.02(S D=8.57)$.
Regarding educational achievement, the majority of investors (98\%) had completed university studies and $5 \%$ of them had finished Master or $\mathrm{PhD}$ programs. The average investment experience was 7.6 years $(S D=6.04)$ with an average bet between twenty thousands and five hundred euros.

\section{Instrument}

Intention, attitude, subjective norm, perceived behavioral control and believes were measured by means of a self-applied questionnaire on 5-point scales (anchor ratings were 1 and 5). All items were based in Ajzen (2006) specifications of elaborating the questionnaire.

Final Behavior (FB): One month after the application of the questionnaire, we contacted investors asking them how many times they had invested each week in the last month.

Intention (I): A single item was used to assess investors' intention, asking whether they planned to invest in stock exchange during the next month.

Attitude (A): Five items were used to assess attitude, by asking investors whether it would be beneficial, good, valuable, pleasant, and enjoyable to invest in the stock exchange.

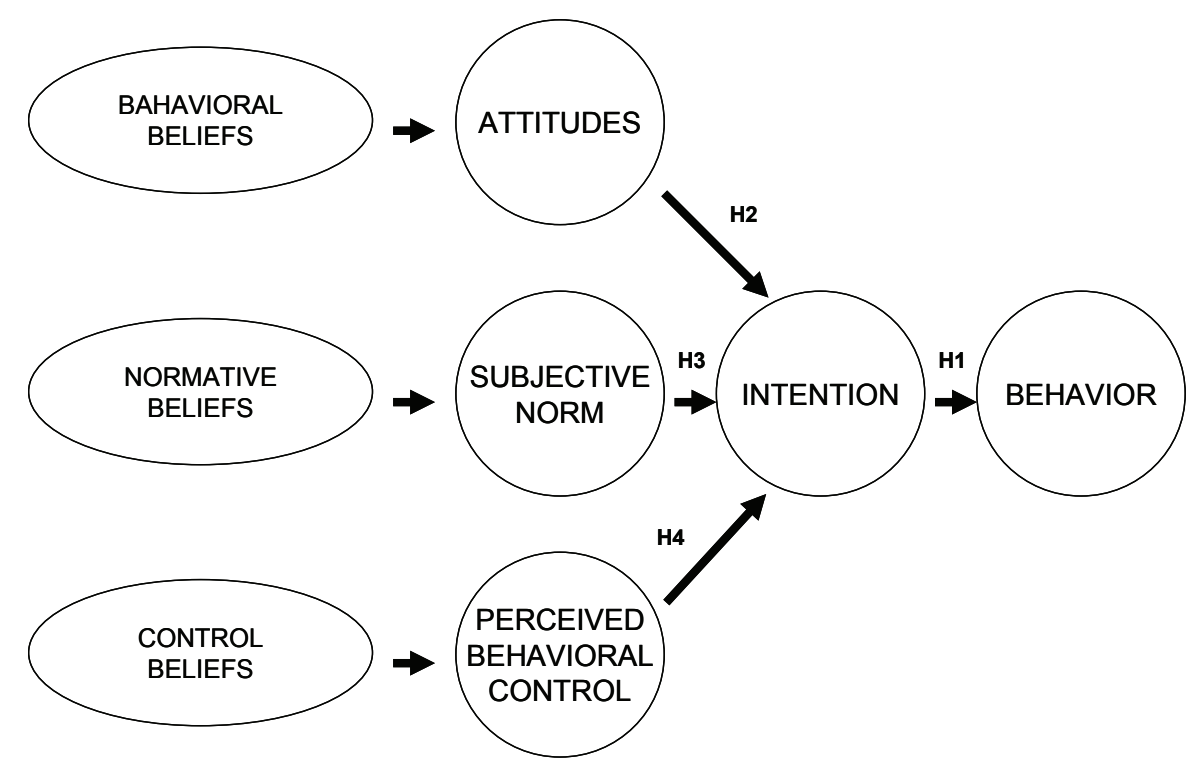

Figure 1. TCP Hypothesis (Path analysis).

Source: Own work. 
Subjective norm (SN): Three items used to assess subjective norm asked them whether people who are important in their lives approve, expect and think that they should invest in the stock exchange.

Perceived behavioral control (PBC): It was measured by a four items scale in the following way: (a) For me it's possible ...; (b) If I wanted to I could ...; (c) How much control do you believe you have over ...; (d) It is mostly up to me whether or not ... invest in the stock exchange.

Believes (B): As Ajzen (2006) suggests, a pilot work is required in order to identify accessible behavioral, normative, and control beliefs. Firstly, respondents were given a description of the behavior and a few questions about it by means of interviews. Responses were used to identify personal salient beliefs and to construct a list of modal salient beliefs. Then, modal salient beliefs provided the basis for constructing the standard questionnaire that was finally used in the study. Expected consequences were the following: To obtain profit, diversify investment and risk, have liquidity, have fun, increase economic risk, and increase the risk of making mistakes. External factors were: specialized knowledge, access to information, sufficient information, initial economic resources, using electronic banks, consulting the available information, having available time, and resorting to intermediaries. We considered as reference groups the following: family, job peers, friends, brokers, and specialized media.

\section{Procedure}

We contacted investors in the Spanish Stock Exchange by e-mail. Our objective was to create a contact chain to increase the number of potential investors. We sent an e-mail to all of our contacts, friends, family and workmates, requesting to fill out the questionnaire if they were investors in the stock market. All of them had to forward the message to all of their contacts, also requesting to fill out the questionnaire if they were investors. Each investor in the sample received a copy of the questionnaire by e-mail, together with instructions about how to fill it out and a few demographic questions about themselves. All participants were reassured about the anonymity and confidentiality of the treatment of their responses.

\section{Statistical Analyses}

Research hypotheses were tested using Path Analysis in a structural equation modeling (SEM). Variables including more than one item were introduced in the model by means of item average. The hypothesized model was estimated with maximum likelihood procedures and assessed using LISREL 8.72 for Windows (Jöreskog \& Sörbom, 1993). SEM assumes linear relationships among variables, and tests these relationships against the data collected. The analytical procedure assumes a causal structure between exogenous and endogenous variables, and allows the estimation of direct, indirect, and total effects (Kline, 1998).

Following the recommendations of $\mathrm{Hu}$ and Bentler (1995), the model fit was evaluated by means of various goodness of fit index. In addition to chi-square, we use chi-square divided by the degrees of freedom, which is less sensitive to sample size. For this estimation, values below three are considered satisfactory (Bollen \& Long, 1993). Other indices were the root mean square error of approximation (RMSEA), the goodness of fit index (GFI), the comparative fit index (CFI), the normed fit index (NFI) and the no normed fir index (NNFI). For the RMSEA, values below 0.05 are considered as a good fit, values between 0.05 and 0.08 as acceptable, and values higher than 0.08 as reasonable errors of approximation in the population (Browne \& Cudeck, 1992). The GFI should be above 0.9 (Bentler, 1992), as should the NFI and the CFI. Other authors are more exigent and accept some index above 0.95 (Schermelleh-Engel $\&$ Moosbrugger, 2003).

\section{Results}

Path Analysis (Figure 1) for the 127 individual investors sample shows that TPB predicts investment behavior (48\%) and intention (63\%), and the results suggested an adequate model fit $(\mathrm{CFI}=1.0$; NFI 
$\left.=0.98 ; \mathrm{GFI}=0.98 ; \chi^{2}=3.29 ; d f=9 ; p<0.05\right)$ as we can see in Table 1 .

We explored the observed pair-wise correlation between the variables included in the model (Table 2). Individual investor's intention is posi- tively correlated with investment behavior ( $\mathrm{H} 1$ : 0.25 with $p<0.01$ ), and individual investor's attitudes and control toward investing in stocks exchange are positively associated with behavioral intentions (H2: 0.53 and $\mathrm{H} 4: 0.2 ; p<0.01$ for

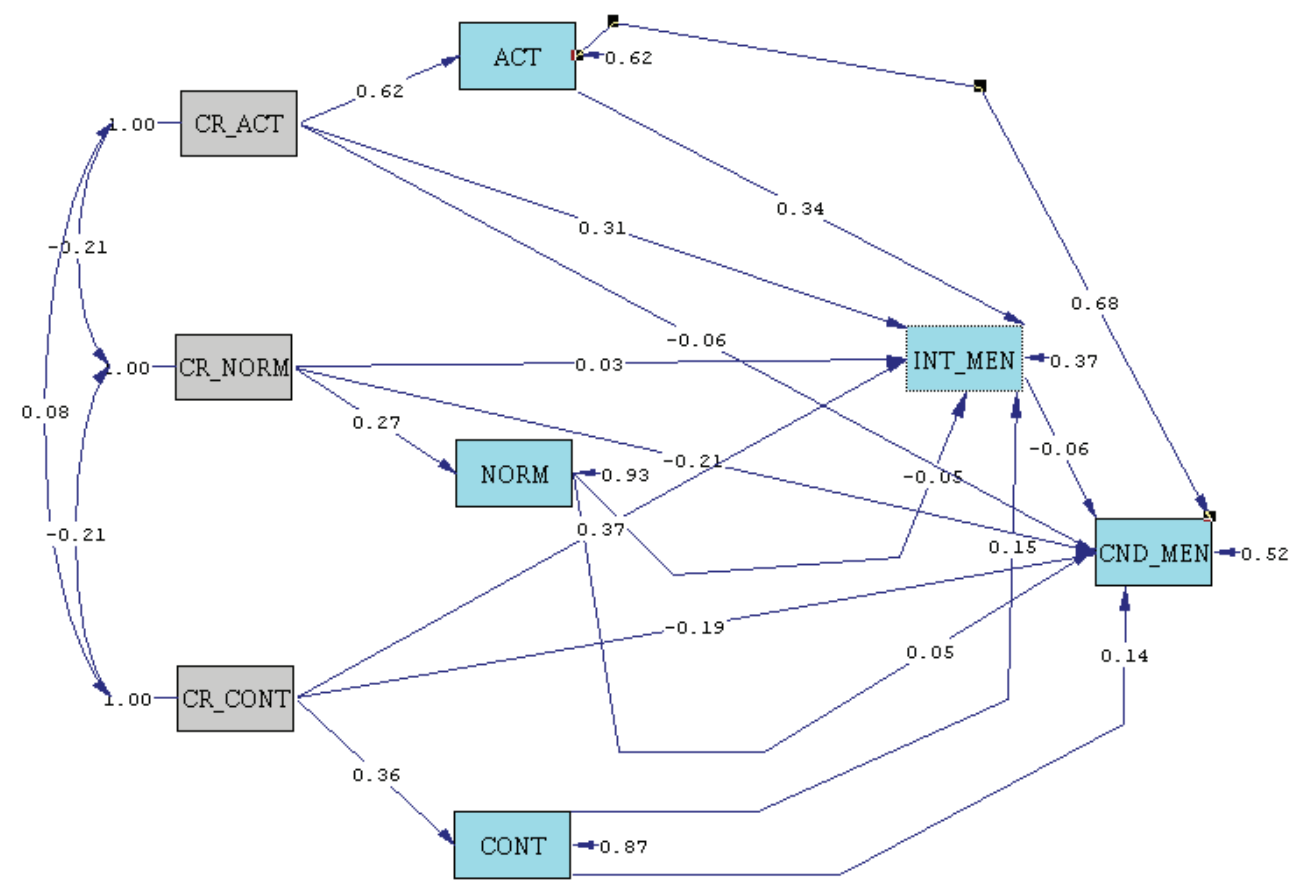

Figure 1. Path analysis.

Source: Own work.

TABLE 1

Fit Index

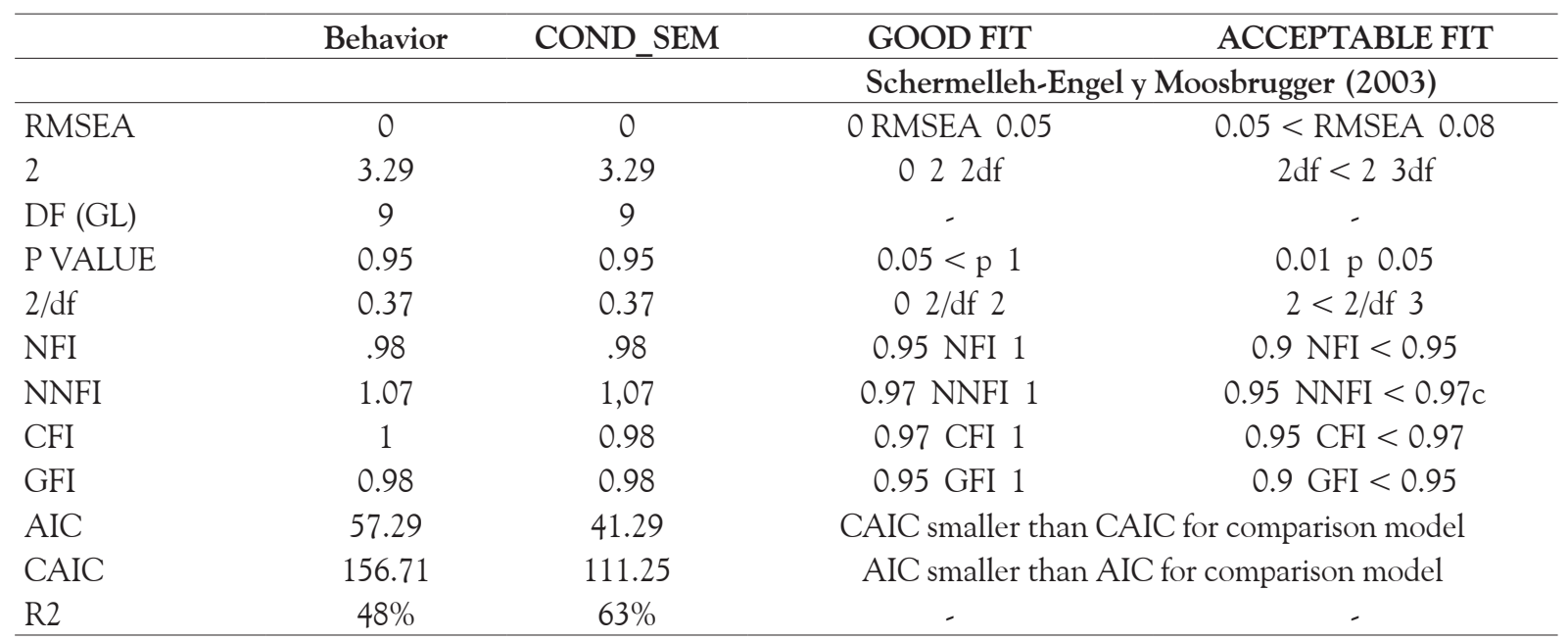

Source: Schermelleh-Engel, K \& Moosbrugger, H. (2003). 
both). On the other hand, individual investor's subjective norms are not positively associated with behavioral intentions, so we cannot maintain $\mathrm{H} 3$. Attitudinal beliefs and control beliefs are also related to the intention to invest in the stock market during the next month.

The correlation index between attitudinal beliefs and intention $(0.48$ with $p<0.01)$ is essentially the same as the correlation index between attitude and intention, whereas the correlation index between control beliefs and intention ( 0.31 with $p<$ 0.01) is clearly higher than the correlation index between perceived control and intention. We can also maintain $\mathrm{H} 5$ because attitudinal beliefs are positively related to attitude $(0.76$ with $p<0.01)$, normative beliefs are related to the subjective norm $(0.2$ with $p<0.01)$ and control beliefs to perceived control $(0.24$ with $p<0.01)$. Therefore, we can maintain $\mathrm{H} 1, \mathrm{H} 2, \mathrm{H} 4$ and $\mathrm{H} 5$ but not H3 (Figure 1).

\section{Discussion}

Taking into account the percentage of explained variance of intention and behavior in the most recent meta-analyses about TPB (in a variety of different behaviors - between 39\% and $42 \%$ and between $27 \%$ and $34 \%$ respectively for intention and behavior (Armitage \& Conner, 2001; Godin \& Kok, 1996; Sheeran \& Taylor, 1999)- our results are more than satisfactory: $63 \%$ of investment intention and $48 \%$ of investment behavior, as well as the good fit index for the model.
Retaking the hypothesis mentioned in the introduction, and according to the results found, we are going to comment each variable described in the TPB and its relevance in order to understand and predict individual investors behavior.

Regarding Intention, we have found that the intention towards investing in stocks exchange is positively associated with the behavior towards investing. This result is in accordance to social psychology researchers, also considering intention as a very important variable in the study of behavior (Ajzen \& Fishbein, 1980). However, it has not been considered very important by investment researchers with several exceptions in the recent years (e.g. Mayfield, Perdue, \& Wooten, 2008).

On the other hand, and as predicted, attitudes in the TPB model are positively associated with behavioral intentions towards investing in stocks exchange. In fact, it has been the variable with the strongest correlation both with intention and behavior. Lee (2009) found attitude as the most relevant variable to explain online trading intention (although behavior was not measured), as well as Ramayah et al. (2009) to explain intention to use Internet stock trading. In the same vein, Van Raaij and Gianotten (1990), and more recently Brown, Taylor, and Wheatley Price (2005), found that the more optimistic people are, the more likely they are to borrow money. Specifically, people with more positive attitudes towards borrowing money are more likely to use credit, than people who hold negative attitudes about borrowing (Livingstone \& Lunt, 1992). Altogether these results

TABLE 2

Means, Standard Deviations, Cronbach `s Alpha and Correlation for Variables

\begin{tabular}{|c|c|c|c|c|c|c|c|c|c|c|c|}
\hline & Mean & $\mathrm{Sd}$ & $\alpha$ Cronbach & Behavior & Intention & Attiude & Subj..Nor & Control & $\begin{array}{c}\text { Att. } \\
\text { Beliefs }\end{array}$ & $\begin{array}{l}\text { Norm. } \\
\text { Beliefs }\end{array}$ & $\begin{array}{l}\text { Cont. } \\
\text { Beliefs }\end{array}$ \\
\hline Behavior & 4,14 & 0.73 & -. & .- & $0.25 * *$ & $0.65 * *$ & -0.12 & 0.11 & $0.51 * *$ & -0.15 & 0.02 \\
\hline Intention & 4.09 & 0.72 & -. & & .. & $0.53 * *$ & -0.13 & $0.21 *$ & $0.48 * *$ & -0.1 & $0.32 * *$ \\
\hline Attiude & 4.13 & 0.67 & 0.732 & & & .. & $-0.23 *$ & 0.09 & $0.76 * *$ & -0.14 & 0.15 \\
\hline Subj..Nor & 3.75 & 0.98 & 0.843 & & & & .. & 0.14 & -0.09 & $0.2 *$ & 0.01 \\
\hline Control & 4.27 & 0.55 & 0.763 & & & & & .. & 0.14 & 0.06 & $0.23 * *$ \\
\hline Att.Beliefs & 4.07 & 0.33 & 0.662 & & & & & & .. & -0.09 & 0.14 \\
\hline Norm.Beliefs & 3.25 & 0.54 & 0.69 & & & & & & & .. & -0.17 \\
\hline Cont.Beliefs & 3.81 & 039 & 0.623 & & & & & & & & .. \\
\hline$* *$ & \multicolumn{2}{|c|}{$\mathrm{p}<0.01$} & & & & & & & & & \\
\hline$*$ & \multicolumn{2}{|c|}{$\mathrm{p}<0.05$} & & & & & & & & & \\
\hline
\end{tabular}


point out the necessity to study attitude to understand not only investors' intentions (as shown in present and other works), but also investors' behavior; as shown in the present work.

About Subjective Norm, the perception of the importance that the "other important" for the investors may have in the final decision to make or not a certain conduct (Ajzen \& Fishbein, 1980), according to our data, it is not clear to be an important variable to predict individual investors intentions to invest. In the study of individual investors' behavior, several authors through the last years have studied Subjective Norm. Investors' decisions may be influenced by other investors' commentaries or by popular beliefs and conversations between investors (Hirshleifer, 2001; Shiller, 1990; Shiller \& Pound, 1989). Moreover, the perception of self-confidence could also increase because of these conversations, making it difficult to distinguish between relevant and irrelevant information of the investment (Hirshleifer, 2001).

However, in our model, subjective norm is not positively associated with behavioral intentions toward investing in stocks exchange. One possible explanation is suggested by Trafimow and Fishbein (1994), for whom the differential weight of the attitudinal and normative components depend on the considered behavior, or even on individual characteristics (Ajzen \& Fishbein, 2005). In fact, Lee (2009) also found a very poor role of subjective norm in stock trading intention. Another explanation (or even a complementary explanation) could be based in the proposal written by Cooke and Sheeran (2004). They pointed out that a strong explanatory power of attitudes can hide the explanatory power of subjective norm, and in that case, attitudes would be positively associated not only with behavioral intentions but also with behavior directly, which is exactly the case of our results.

Therefore and according to Cooke and Sheeran (2004), redoing the analysis, when we removed attitudes from the model, subjective norm is more important, and is in fact positively correlated with behavioral intentions; although the model loses explanatory power. With all this in mind, we should not forget that financial transactions may be very private for many people; thus, possibly people could be less influenced by norms, in contrast to other social behaviors. Also, some individuals may motivate people more than others depending on their perceived competence with the stock market.

Another important component of the TPB is Control, which has not been one of the most popular variables in the field of investment analysis. However, our study supports the importance of control, as well as other applications of the model in similar behaviors (East, 1993; Lee, 2009; Ramayah et al., 2009). In fact, there is some work analyzing the importance of perceived control of investors' behavior in the stock markets. Thaler (1980) demonstrated that if the investor perception of control is high, they tend to be more self-confident on their investment and they also invest bigger amounts of money.

Finally, Beliefs, predecessors of attitude, subjective norm and control in the TPB, have also been relevant in the study of individual investors' behavior. Like in other components of the model, we have found that an individual investor's beliefs toward attitudes and perceived behavioral control are positively associated with attitudes and control, respectively and indirectly, with behavioral Intentions towards investing in stocks exchange. According to this, others have found beliefs as important factors to understand the investor behavior. Weinstein (1980) found that individual investors' beliefs with regard to their real abilities to invest were too optimistic. In addition, modifying beliefs after new events take a long time, and when those events are highly shocking, modification is stronger (Edwards, 1968). Odean (1998) also found that investors have the false belief that losses and gains are "reverted", so that many investors prefer to sell under winning positions and to maintain their money under losing situations.

According to the results of the present study, the model proposed by the Theory of Planned Behavior (Ajzen, 1991) seems an efficacious tool to explain and predict individual investors' behavior in stock markets. In fact, the model explains almost two thirds of the variance of the intention to invest in the stock market, and about a half of the variance of behavior. Therefore, from a methodological point 
of view, these results are satisfactory if we compare them with previous results of the model. Probably one of the most important results found in the present work is the fact that variables like attitudes and control, which are not usually studied in the field of investors' behavior, must be two key variables to study, in order to understand and predict not only investors' intentions but also their behavior. These results point out the evident need to introduce psychological factors to understand human behavior in the stock market. There is a need to strengthen economic and psychological fields in order to understand certain human behaviors in the economic field, such as individual investors' behavior.

However, this study has also some limitations in an applied business world. Although in social sciences, explaining $40 \%$ - $60 \%$ of intention or behavior is considered a noteworthy accomplishment, for banking financial advisors who need to understand customer/investor behavior in order to suggest different investment alternatives, the prediction of the $50 \%$ of behavior or the $60 \%$ of intention according to the TPB may be unsatisfactory results. Also, the sample is not very large and perhaps it is not sufficiently representative of a larger population, however, it is ideal for our purposes, as we are using real individual investors, contrary to other studies that use student samples.

We need to leap in order to build a more consistent bridge between theoretical academic fields and daily companies' activities. Therefore, further research must be focused on improving existing models or proposing new ones, which allow us to apply the results found in basic research. We really think that the study of psychological factors, such as attitudes and control may be a good start to advance in the knowledge of individual investors' behavior in the stock markets.

\section{References}

Ajzen, I. (1991). The Theory of Planned Behavior. Organizational Behavior and Human Decision Processes, 50(2), 179-211.

Ajzen, I. (2002). Perceived behavioral control, self-efficacy, locus of control, and the Theory of Planned
Behavior. Journal of Applied Social Psychology, 32(4), 665-683.

Ajzen, I. (2006). Constructing a TpB Questionnaire: Conceptual and Methodological Considerations. Retrieved from http://www.people.umass.edu/ aizen/pdf/ tpb.measurement.pdf

Ajzen, I., \& Fishbein, M. (1980). Understanding attitudes and predicting social behavior. Englewood Cliffs, NJ: Prentice-Hall.

Ajzen, I., \& Fishbein, M. (2005). The influence of attitudes on behavior. In D. Albarracín, B. T. Johnson \& M. P. Zanna (Eds.), The handbook of attitudes (pp. 173-221). Mahwah, NJ: Lawrence Erlbaum Associates.

Anand, P., \& Cowton, C. (1993). The ethical investor: Exploring dimensions of investment behaviour. Journal of Economic Psychology, 14(2), 377-385.

Armitage, C. J., \& Conner, M. (2001). Efficacy of the Theory of Planned Behaviour: A meta-analytic review. British Journal of Social Psychology, 40(4), 471-499.

Bagozzi, R. P., \& Kimmel, S. K. (1995). A comparison of leading theories for the prediction of goal-directed behaviors. British Journal of Social Psychology, 34(4), 437-461.

Barber, B. M., \& Odean, T. (2011, September). The behavior of individual investors. Working Papers Series. Davis/Berkeley, CA: University of California, Haas School of Business. Available at SSRN: http://ssrn.com/abstract $=1872211$

Barberis, N., Shleifer, A., \& Vishny, R. (1998). A model of investor sentiment. Journal of Financial Economics, 49(3), 307-343.

Bentler, P. M. (1992). EQS structural equations program manual. Los Angeles: BMDP Statistical Software.

Bollen, K. A., \& Long, J. S. (1993). [Introduction]. In K. A. Bollen \& J. S. Long (Eds.), Testing structural equation models (pp. 1-9). Newbury Park, CA: Sage.

Brown, S., Taylor, K., \& Wheatley Price, S. (2005). Debt and distress: Evaluating the psychological cost of credit. Journal of Economic Psychology, 26(5), 642-663.

Browne, M. W., \& Cudeck, R. (1992). Alternative ways of assessing model fit. Sociological Methods and Research, 21(2), 230-258. 
Cooke, R., \& Sheeran, P. (2004). Moderation of cognition-intention and cognition-behavior relations: A meta-analysis of properties of variables from the theory of planned behavior. British Journal of Social Psychology, 43(2), 159-186.

East, R. (1993). Investment decisions and the theory of planned behaviour. Journal of Economic Psychology, 14(2), 337-375.

Edwards, W. (1968). Conservatism in human information processing. In B. Kleinmutz (Ed.), Formal representation of human judgment (pp. 17-52). New York: Wiley.

Fazio, R. H. (1986). How do attitude guide behavior? In R. Sorrentino \& E. T. Higgins (Eds.), Handbook of motivation and cognition: Foundation of social behavior (pp. 204-243). New York: Guilford Press.

Fishbein, M., \& Ajzen, I. (1975). Belief, attitude, intention and behavior: An introduction to theory and research. Reading, MA: Addison-Wesley.

Godin, G., \& Kok, G. (1996). The theory of Planned Behavior: A review of its applications to healthrelated behaviors. American Journal of Health Promotion, 11(2), 87-98.

Grandon, E. E. (2005). Extension and validation of the Theory of Planned Behavior: The case of electronic commerce adoption in small and medium-sized businesses in Chile. PhD Thesis, Southern Illinois University at Carbondale, Illinois, United States.

Hirshleifer, D. (2001). Investor psychology and asset pricing. The Journal of Finance, 56(4), 1533-1597.

Hofmann, E., Penz, E., \& Kirchler, E. (2009). The 'whys' and 'hows' of ethical investment: Understanding an early-stage market through an explorative approach. Journal of Financial Services Marketing, 14(2), 102-117.

Hrubes, D., Ajzen, I., \& Daigle, J. (2001). Predicting hunting intentions and behavior: An application of the Theory of Planned Behavior. Leisure Sciences, 23(3), 165-178.

Hu, L. T., \& Bentler, P. M. (1995). Evaluating model fit. In R. H. Hoyle (Ed.), Structural equation modelling: Concepts, issues and applications (pp. 77-99). Thousand Oaks, CA: Sage.

Jansson, M., \& Beil, A. (2006, September). Psychological influences on investors intention to be socially responsible investors: A comparison what influences SRI intentions among different types of investors (SIRP WP 09-06). Stockholm, Sweden: Sustainable Investment and Corporate Governance Working Papers, Sustainable Investment Research Platform.

Jöreskog, K. G., \& Sörbom, D. (1993). LISREL 8: Structural equation modelling with the SIMPLIS command language. Chicago: Scientific Software.

Kline, R. B. (1998). Principles and practice of structural equation modeling. New York: The Guilford Press.

Kurland, N. B. (1996). Sales agents and clients: Ethics, incentives, and a modified Theory of Planned Behavior. Human Relations, 49(1), 51-74.

Lee, M. C. (2009). Predicting and explaining the adoption of online trading: An empirical study in Taiwan. Decision Support Systems, 47(2), 133-142.

Lee-Partridge, J., \& Ho, P. S. (2003, January). A retail Investor's perspective on the acceptance of internet stock trading. Proceedings of the 36th Hawaii International Conference on System Sciences. Available at http://www.hicss.hawaii.edu/hicss36/ hicsspapers/inemg02.pdf

Livingstone, S. M., \& Lunt, P. K. (1992). Predicting personal debt and debt repayment: Psychological, social and economic determinants. Journal of Economic Psychology, 13(1), 111-134.

Lovric, M., Kaymak, U., \& Spronk, J. (2008, June). A conceptual model of investor behavior (Erasmus Research Institute of Management (ERIM), Report Series Research in Management No. ERS-2008. 030-F\&A). Rotterdam, Netherlands: Erasmus Universiteit.

Mayfield, C., Perdue, G., \& Wooten, K. (2008). Investment management and personality type. Financial Services Review, 17(3), 219-236.

Oberlechner, T., \& Hocking, S. (2004). Information sources, news, and rumors in financial markets: Insights into the foreign exchange market. Journal of Economic Psychology, 25(3), 407-424.

Odean, T. (1998). Are investors reluctant to realize their losses? The Journal of Finance, 53(5), 1775-1798.

Ramayah, T., Rouibah, K., Gopi, M., \& Rangel, G. J. (2009). A decomposed theory of reasoned action to explain intention to use Internet stock trading among Malaysian investors. Computers in Human Behavior, 25(6), 1222-1230. 
Rouibah, K., Ramayah, T., \& May, O. S. (2009). User acceptance of internet banking in Malaysia: Test of three acceptance models. International Journal for E-Adoption, 1(1), 1-19.

Schermelleh-Engel, K., \& Moosbrugger, H. (2003). Evaluating the fit of structural equation models: Tests of significance and descriptive goodnessof-fit measures. Methods of Psychological Research Online, 8(2), 23-74.

Sheeran, P. (2002). Intention-behavior relations: A conceptual and empirical review. In W. Stroebe \& M. Hewstone (Eds.), European review of social psychology (Vol. 12, pp. 1-36). Chichester, UK: Wiley.

Sheeran, P., \& Taylor, S. (1999). Predicting intentions to use condoms: A meta-analysis and comparison of the theories of reasoned action and planned behavior. Journal of Applied Social Psychology, 29(8), 1624-1675.

Shih, Y. Y., \& Fang, K. (2004). The use of decomposed theory of planned behavior to study internet banking in Taiwan. Internet Research, 14(3), 213-223.

Shiller, R. J. (1990). Market volatility and investor behavior. The American Economic Review, 80(2), 58-62.

Shiller, R. J., \& Pound, J. (1989). Survey evidence on diffusion of interest and information among institutional investors. Journal of Economic Behavior and Organization, 12(1), 47-66.
Singh, A., Sandhu, H. S., \& Kundu, S. C. (2010). Investors' adoption of internet stock trading: A study. Journal of Internet Banking and Commerce, 15(1), $1-21$.

Thaler, R. (1980). Toward a positive theory of consumer choice. Journal of Economic Behavior and Organization, 1(1), 39-60.

Trafimow, D., \& Fishbein, M. (1994). The moderating effect of behavior type on the subjective normbehavior relationship. The Journal of Social Psychology, 134(6), 755-763.

Trafimow, D., Sheeran, P., Conner, M., \& Finlay, K. A. (2002). Evidence that perceived behavioral control is a multidimensional construct: Perceived control and perceived difficulty. Bristish Journal of Social Psychology, 41(1), 101-121.

Van Raaij, W. F., \& Gianotten, H. J. (1990). Consumer confidence, expenditure, saving and credit. Journal of Economic Psychology, 11(2), 269-290.

Wang, Y., Zhang, Z., \& Hua, R. (2011). Investor behavior and volatility of futures market: A theory and empirical study based on the OLG Model. Frontiers of Business Research in China, 5(3), 512-536.

Weinstein, N. (1980). Unrealistic optimism about future life events. Journal of Personality and Social Psychology, 39(5), 806-820.

Wong, P. K., \& Ho, Y. P. (2007). Characteristics and determinants of informal investment in Singapore. Venture Capital, 9(1), 43-70. 
